\title{
Recovery of copper (II) absorbed in biomass of Cladosporium cladosporioides
}

\author{
Juliana Ribeiro do Carmo *, Carlos José Pimenta, Júlia Ferreira da Silva§, Sara Maria Chaulfoun de Souza
}

UFLA/DCA - Depto. de Ciência dos Alimentos, C.P. 3037 37200-000 - Lavras, MG - Brasil.

*Corresponding author <julianaribeirocarmo@hotmail.com>

Edited by: Cláudio Marcelo Gonçalves de Oliveira

Received January 28, 2012

Accepted September 21, 2012
ABSTRACT: The biosorption process, characterized by the use of biomass for removing metals from aqueous solutions, is an attractive technology using inactive and dead biomasses to remove heavy metals from aqueous solutions in the absence of metabolic activity necessary for intracellular accumulation. The desorption process, which concentrates the metal previously absorbed for possible reuse, is also important. The desorption of copper (Cu) (II) associated with the biomass of Cladosporium cladosporioides (Fres) de Vries was evaluated following the biosorption process (adsorption). Specifically, four eluents were used (all at a concentration $0.1 \mathrm{~mol} \mathrm{~L}^{-1}$ ), sulfuric acid, hydrochloric acid, ethylenediaminetetraacetate disodium and calcium chloride, as well as the recovery of $\mathrm{Cu}$ (II) desorbed as copper sulfate. After $120 \mathrm{~h}, 97 \%$ of $\mathrm{Cu}$ in solution had been adsorbed. C. cladosporioides can efficiently adsorb $\mathrm{Cu}$ (II). Further, $0.1 \mathrm{~mol}$ $\mathrm{L}^{-1}$ sulfuric acid was viable and the most efficient for the desorption of the absorbed metal, while ensuring viability of $C$. cladosporioides after desorption, which is important for the reuse of the biomass in cycles of sorption-desorption.

Keywords: biosorption, metal, desorption

\section{Introduction}

Biosorption is a technology that is based on the removal of heavy metals by biomass present in aqueous solutions through passive means; that is, the mechanism of removal is not metabolically controlled (Davis et al., 2003). Biosorption is a potentially important mechanism for heavy metal cleanup relative to conventional methods due to its low cost, high efficiency and the possibility of the regeneration and recovery of the metals (Cruz et al., 2004; Luo et al., 2010). The biosorption does not replace methodologies used for removal of metals (such as precipitation, reduction, ion exchange, adsorption and coagulation); however, it can act as a system polishing in processes that are not completely efficient. The desorption of heavy metals in biosorbents can be accomplished with the use of eluents (agent competitors), which have different modes of interaction with biomass that has accumulated metals, allowing some percentage of recovery (Seolatto et al., 2009; Suhasinia et al., 1999).

The biomass of Cladosporium is an efficient biosorbent of copper - $\mathrm{Cu}$ (II), cyanide, nickel, organochlorine pesticides, cadmium, silver, gold, and several organic compounds, including aromatic hydrocarbons, ketones and organic acids (Buszman et al., 2006; Juhasz et al., 2002; Pethkar et al., 2001a,b; Qi et al., 2002). While Cu (II) is an important trace element for the growth of these fungi, it can be toxic in high concentrations. An effective biosorbent for $\mathrm{Cu}$ (II) must be able to withstand high concentrations of this metal found in contaminated wastes (Melgar et al, 2007), for example, with pesticides used in agricultural production (Andreazza et al., 2010; Dell'Amico et al., 2008). The process of desorption of the

spresent address: UFBA/Instituto de Ciências Ambientais e Desenvolvimento Sustentável, R. Professor José Seabra, s/n - 47805-100 - Barreiras, BA Brasil. metals that are biosorbed from the water, and its concentration for subsequent use, is as important as the biosorption process. Thus, the aim of the present study was to evaluate the desorption of $\mathrm{Cu}$ (II) by Cladosporium cladosporioides (Fres) de Vries biomass through biosorption (adsorption) using sulfuric acid, hydrochloric acid, ethylenediaminetetraacetate disodium and calcium chloride, as well as $\mathrm{Cu}$ (II) desorbed as copper sulfate $\left(\mathrm{CuSO}_{4}\right)$.

\section{Materials and Methods}

This study focused on the filamentous fungi, $C$. cladosporioides, isolate G088, obtained from coffee beans. Cladosporium cladosporioides was first cultivated in the middle of solidified potato-dextrose-agar (PDA), inoculated with chloramphenicol antibiotic, and incubated at $25^{\circ} \mathrm{C}$ for 10 days. After this period, three discs $(6 \mathrm{~mm}$ in diameter each) of the fungus were transferred to Erlenmeyer flasks of $250 \mathrm{~mL}$ with $100 \mathrm{~mL}$ of medium potatodextrose (PD). Twenty flasks were used, each containing three discs of $C$. cladosporioides. After $5 \mathrm{~h}$-agitation at $120 \mathrm{rpm}$ at $25^{\circ} \mathrm{C}$ in an orbital shaker, the flasks were incubated at $25^{\circ} \mathrm{C}$ for 20 days. After this period, the biomass was filtered and washed with distilled water four times to remove the middle of the culture.

For adsorption, $20 \mathrm{~g}$ of wet biomass of C. cladosporioides were transferred to a $250 \mathrm{~mL}$-Erlenmeyer flask containing $150 \mathrm{~mL}$ of copper sulfate pentahydrate $/ \mathrm{Cu}$ $\mathrm{SO}_{4} \cdot 5 \mathrm{H}_{2} \mathrm{O}$ ), with a concentration of $20 \mathrm{mg} \mathrm{L}^{-1}$, which contained the initial concentration of $4.8 \mathrm{mg} \mathrm{L}^{-1}$ of $\mathrm{Cu}$ (II). This procedure was replicated 12 times. The adsorption test was carried out in a finite bath for $120 \mathrm{~h}$ and was agitated at $120 \mathrm{rpm}$ at $25^{\circ} \mathrm{C}$. The concentration factor $(\mathrm{CF})$ was calculated by $C F=C / C o$, where $\mathrm{C}$ is the adsorbed $\mathrm{Cu}$ (II) concentration and $\mathrm{Co}$ is the initial $\mathrm{Cu}$ (II) concentration. To achieve kinetic adsorption of $\mathrm{Cu}$ (II), aliquots of $10 \mathrm{~mL}$ of the solution that contained the 
fungus were flooded during the following periods: $0 ; 0.5$; $1 ; 2 ; 4 ; 6 ; 8 ; 10 ; 22 ; 24 ; 48 ; 72 ; 96$ and 120 h. Samples were filtered on filter paper and analyzed for $\mathrm{Cu}$ (II) absorption by atomic spectrometry.

Viability of C. cladosporioides after adsorption: three discs (6.0 $\mathrm{mm}$ diameter) were removed from the $\mathrm{Cu}$ (II) solutions after $120 \mathrm{~h}$ of adsorption, transferred to Petri dishes with solidified PDA and chloramphenicol antibiotic and incubated at $25{ }^{\circ} \mathrm{C}$ for 10 days. Fungal growth was visually compared to control treatments where there was no chemical treatment.

Desorption of $\mathrm{Cu}$ (II) by C. cladosporioides: after $120 \mathrm{~h}$ of contact with the $\mathrm{Cu}$ (II) solution, the contaminated biomass was filtered and rinsed five times with distilled water to remove superficially deposited $\mathrm{Cu}$ (II). After it was filtered and rinsed, the biomass was placed in contact with one of the following $0.1 \mathrm{~mol} \mathrm{~L}^{-1}$ eluent solutions: sulfuric acid, hydrochloric acid, ethylenediaminetetraacetate disodium and calcium chloride, to determine the amount by which they desorbed the $\mathrm{Cu}$ (II) that was previously adsorbed.

For the desorption stage, 20 samples of $5 \mathrm{~g}$ of biomass (five samples for each eluent) were placed in contact with $100 \mathrm{~mL}$ of the eluent solution in $250 \mathrm{~mL}$ Erlenmeyer flasks. The entire system (biomass contaminated and eluent solution) were agitated at $120 \mathrm{rpm}$ at $25{ }^{\circ} \mathrm{C}$ for $10 \mathrm{~h}$. In order to estimate the process of $\mathrm{Cu}$ (II) desorption, $5 \mathrm{~mL}$ aliquots were removed from each system at the following times: 0, 2, 4, 6, 48 and $100 \mathrm{~h}$. The amount of $\mathrm{Cu}$ (II) was analyzed by atomic absorption spectrometry.

Viability of $\boldsymbol{C}$. cladosporioides after desorption: three discs (6.0 mm diameter) were removed from each eluent solutions after $10 \mathrm{~h}$ of desorption, transferred to Petri dishes with middle solidified PDA (potato-dextrose agar) and chloramphenicol antibiotic, and incubated at $25^{\circ} \mathrm{C}$ for 10 days. The changes in growth were compared (visually) to controls that had not been exposed to chemical treatment.

Recovery of $\mathrm{Cu}$ (II) desorbed as hydrated copper sulfate: sulfuric acid at $0.1 \mathrm{~mol} \mathrm{~L}{ }^{-1}$ had the highest elution capacity of $\mathrm{Cu}$ (II) adsorbed in biomass of C. cladosporioides. To discern how this $\mathrm{Cu}$ (II) could be recovered, the adsorption and desorption processes were repeated for this eluent. Therefore, 12 Erlenmeyer flasks, each containing $20 \mathrm{~g}$ of $C$. cladosporioides and $100 \mathrm{~mL} \mathrm{CuSO}_{4}$. $\mathrm{H}_{2} \mathrm{O}$ solution (at a concentration of $20 \mathrm{mg} \mathrm{L}^{-1}$ ) were incubated at $25{ }^{\circ} \mathrm{C}$ and agitated for $120 \mathrm{~h}$ at $120 \mathrm{rpm}$. Next, the biomass was rinsed five times with distilled water. To repeat the desorption process, 12 Erlenmeyer flasks, each containing $5 \mathrm{~g}$ of washed and filtered biomass (after adsorption) and $100 \mathrm{~mL}$ of sulfuric acid $0.1 \mathrm{~mol} \mathrm{~L}^{-1}$, were incubated at $25^{\circ} \mathrm{C}$ and agitated at $120 \mathrm{rpm}$ for $10 \mathrm{~h}$. Samples were collected at the beginning and end of the adsorption and desorption processes for $\mathrm{Cu}$ (II) analysis using atomic absorption spectrophotometry. After desorption, $900 \mathrm{~mL}$ of sulfuric acid $0.1 \mathrm{~mol} \mathrm{~L}^{-1}$ (containing $\mathrm{Cu}$ II) were obtained. For $\mathrm{Cu}$ (II) precipitation, this volume was reduced to $100 \mathrm{~mL}$ by heating on an electric plate. Five $\mathrm{mL}$ of thioacetamide $3 \% \mathrm{w} / \mathrm{v}$ were added during this process to operate as a source of sulfur for the precipitation of copper sulfide (CuS). The $\mathrm{CuS}$ was dried on an electric plate. To obtain $\mathrm{Cu}$ (II) in the form that was used in the solution for the adsorption test (copper sulfate), hydrogen peroxide $(2 \mathrm{~mL})$ was added to oxidize CuS to copper sulfate.

Statistical Analyses: The experiment was carried out using a completely randomized factorial design with four types of eluent solution and five contact times. Each treatment was replicated five times. The data were analyzed using analysis of variance (ANOVA), the quantitative data (time) were analyzed using linear regression and the qualitative (type of eluent) data were compared with an average means test [Tukey's test $(p<0.05)$ ]. Analyses were performed with SAS software (SAS, 1996).

\section{Results and Discussion}

Process of $\mathrm{Cu}$ (II) adsorption by C. cladosporoides: the reaction kinetics of $\mathrm{Cu}$ (II) adsorption relative to the $\mathrm{Cu}$ (II) remaining in the solution was modeled with a common decay model (Equations 1 and 2).

$\mathrm{dC} / \mathrm{dTc}=-\mathrm{k} \cdot \mathrm{C}$
$C=C o \cdot e^{-K \cdot T c}$

where: $\mathrm{C}=$ Remaining $\mathrm{Cu}$ (II) concentration $\left(\mathrm{mg} \mathrm{L}^{-1}\right)$; $\mathrm{Co}=$ Initial $\mathrm{Cu}(\mathrm{II})$ concentration $(\mathrm{Tc}=0) ; \mathrm{Tc}=$ Contact time (time); $\mathrm{k}=$ Reaction coefficient $\left(\right.$ time $\left.^{-1}\right)$.

The values of the reaction coefficient $(\mathrm{k})$ were correlated with the time of contact. Higher values of $k$ have higher reactions speeds. The adsorption process occurs in two phases, the first having greater speed than the second (higher values of $\mathrm{k}$ ) (Figures $1 \mathrm{~A}$ and $1 \mathrm{~B}$ ). At the beginning of the adsorption process, most of the binding sites are free, and adsorption is fast. According to Silveira and Alleoni (2003), this is due the initial period of the adsorption curve corresponds to a high energy link. The second phase (Figure 1B) occurs due to a release of sites previously saturated by ligands in the first stage that result, for example, from a change in $\mathrm{pH}$ (Kaewsarn, 2002), and this phase occurs more slowly.

The quantity of adsorbed $\mathrm{Cu}$ (II) was calculated by the difference between the initial concentration and the concentration during the different contact times and was reported as the concentration of adsorbed $\mathrm{Cu}$ (II) and the remnants in the solution. After $30 \mathrm{~min}, 71 \%$ of $\mathrm{Cu}$ (II) in the solution had been adsorbed, and after $2 \mathrm{~h}, 94 \%$. At the end of the process of adsorption (i.e., after $120 \mathrm{~h}$ ), a concentration factor of 0.97 was observed. These ad- 

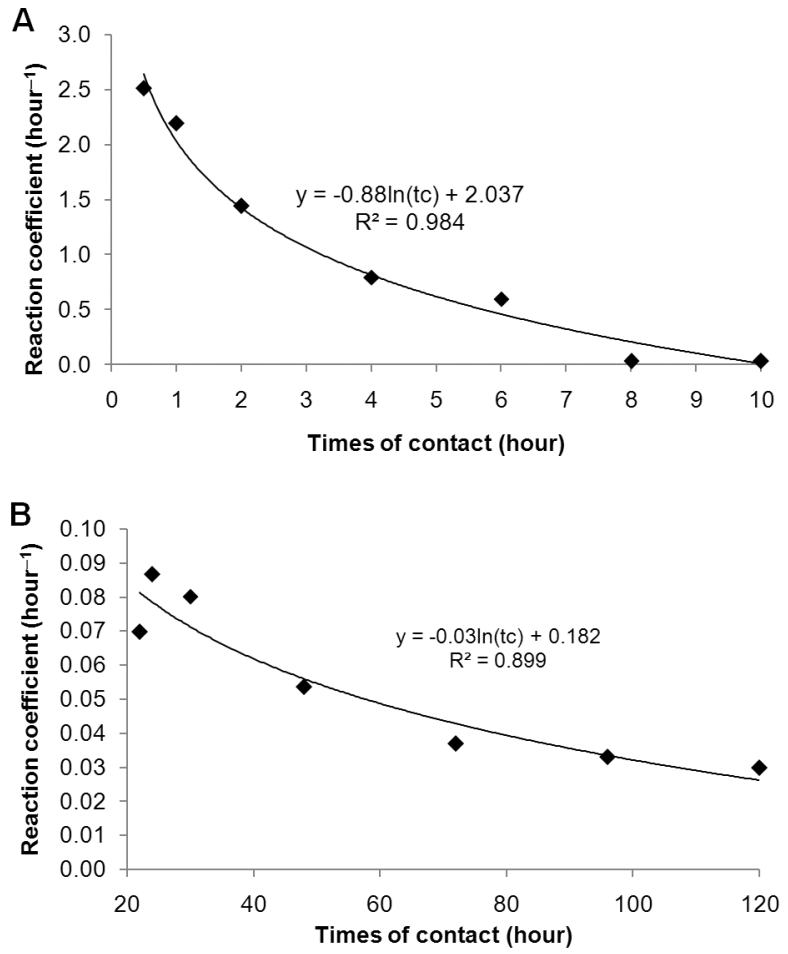

Figure 1 - Effect of contact time at the speed of adsorption (A) first phase and (B) the second phase of copper per biomass of $C$. cladosporioides.

sorption values are close to the $90 \%$ of $\mathrm{Cu}$ (II) removed after 15 min using the alga, Padina sp., as observed by Kaewsarn (2002).

The kinetics of the adsorption reaction indicates that the time of balance (point in which the concentration absorbed is the same to the concentration desorbed) was at $12.7 \mathrm{~h}$ of contact (Figure $2 \mathrm{~A}$ and $2 \mathrm{~B}$ ). Finding the equilibrium time is important because this is when the adsorbed solute can, with a simple change in temperature, concentration or operating pressure, be removed from the adsorbent, hindering the subsequent adsorptive process (Peruch et al., 1998).

Viability of $C$. cladosporioides after adsorption: the visual comparison of the growth of $C$. cladosporioides after immersion in a solution of $\mathrm{CuSO}_{4}$ for $120 \mathrm{~h}$ showed that this does not inhibit the growth of the fungi but delays the start of growth by three days relative to when it was not immersed in a solution of $\mathrm{Cu}$ (II) for 10 days.

Desorption Process of Cu (II) by C. cladosporoides: The mean values of $\mathrm{Cu}$ (II) concentrations desorbed for each type of eluent solution, in each time period, are summarized in Table 1 . A significant interaction was observed $(p<0.01)$ between the time of contact and the type of eluent solution.

The average percentage of desorption in relation to the final quantity of $\mathrm{Cu}$ (II) adsorbed by C. cladospori-
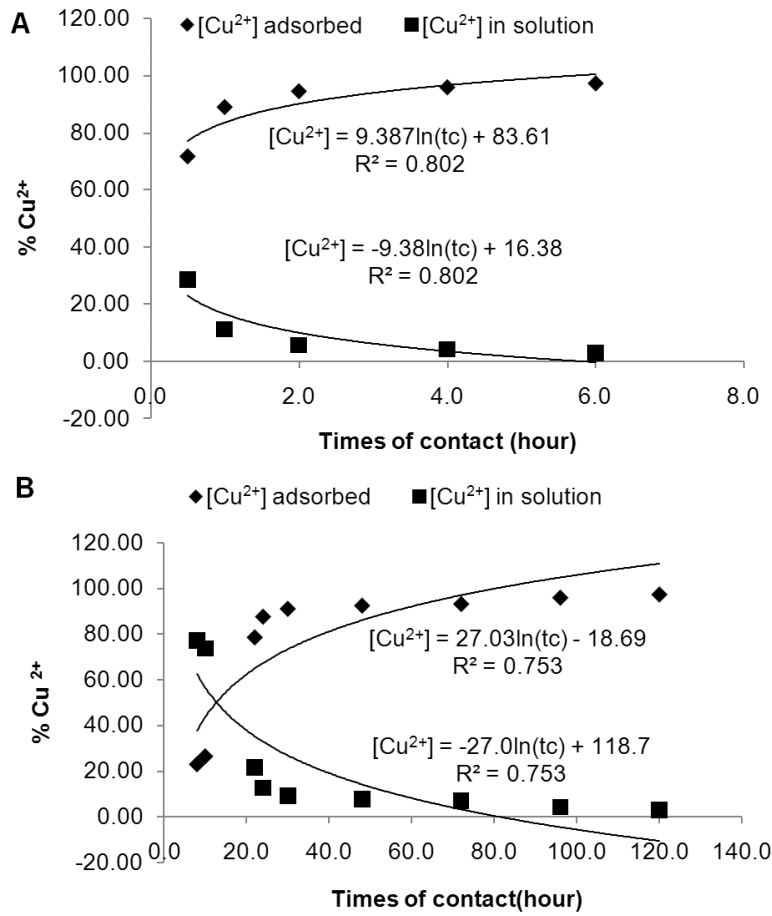

Figure 2 - Adsorption kinetics of copper ( $20 \mathrm{mg} \mathrm{L}^{-1}$ de $\mathrm{CuSO}_{4} .5 \mathrm{H}_{2} \mathrm{O}$ ) for biomass of $C$. cladosporioides (A) 0 to $6 \mathrm{~h}$ and (B) from 8 to $120 \mathrm{~h}$. The graph on kinetics was divided in two because of the lack of adjustment when plotted as a single graph.

Table 1 - Mean concentration* of desorbed copper using $\mathrm{H}_{2} \mathrm{SO}_{4}$, $\mathrm{HCl}$, EDTA-Na ${ }_{2}$ and $\mathrm{CaCl}_{2}$ as eluents.

\begin{tabular}{|c|c|c|c|c|}
\hline \multirow[b]{2}{*}{ Contact time } & \multicolumn{4}{|c|}{ Dessorbed copper } \\
\hline & $\mathrm{H}_{2} \mathrm{SO}_{4}$ & $\mathrm{HCl}$ & EDTA & $\mathrm{CaCl}_{2}$ \\
\hline hour & \multicolumn{4}{|c|}{$\mathrm{mg} \mathrm{L}^{-1}$} \\
\hline 2 & $1.94^{c}$ & $1.48^{b}$ & $1.51^{\mathrm{b}}$ & $0.08^{a}$ \\
\hline 4 & $2.04^{d}$ & $1.63^{\mathrm{b}}$ & $1.75^{c}$ & $0.12^{\mathrm{a}}$ \\
\hline 6 & $2.03^{d}$ & $1.71^{\mathrm{b}}$ & $1.83^{c}$ & $0.14^{a}$ \\
\hline 8 & $2.00^{d}$ & $1.80^{\mathrm{b}}$ & $1.89^{\mathrm{bc}}$ & $0.17^{\mathrm{a}}$ \\
\hline 10 & $2.05^{c}$ & $1.87^{\mathrm{b}}$ & $1.99^{\mathrm{bc}}$ & 0.19 \\
\hline CV (\%) & \multicolumn{4}{|c|}{5.91} \\
\hline
\end{tabular}

${ }^{*}$ Values with the same letters in the row are not different $(p<0.05$; Tukey's test). $\mathrm{H}_{2} \mathrm{SO}_{4}$ - sulfuric acid $\left(0.1 \mathrm{~mol} \mathrm{~L}^{-1}\right) ; \mathrm{HCl}$ - hydrochloric acid $\left(0.1 \mathrm{~mol} \mathrm{~L}^{-1}\right)$, EDTA- $\mathrm{Na}_{2}$ - ethylenediaminetetraacetate disodium $\left(0.1 \mathrm{~mol} \mathrm{~L}^{-1}\right) ; \mathrm{CaCl}_{2}$ - calcium chloride $\left(0.1 \mathrm{~mol} \mathrm{~L}^{-1}\right), \mathrm{CV}$ - coefficient of variation.

oides was $43 \%, 36 \%, 38 \%$ and $3 \%$ for the eluents sulfuric acid, hydrochloric acid, ethylenediaminetetraacetate disodium and calcium chloride, respectively. Similar results regarding the use of inorganic acids for the desorption of metals absorbed in biomasses were reported by Chojnacka et al. (2005), who compared the $0.1 \mathrm{~mol} \mathrm{~L}^{-1}$ of the eluents EDTA- $\mathrm{Na}_{2}$ and $\mathrm{HNO}_{3}$, in the desorption of cadmium (II), chrome (III) and $\mathrm{Cu}$ (II) absorbed in alga Spirulina sp. They found the solution of $\mathrm{HNO}_{3}$ that removed almost all of the linked metallic ions with the biomass (98\%), and it did not cause loss of the biosorption capacity. 
At all evaluated contact times, calcium chloride caused lower desorption of $\mathrm{Cu}$ (II) adsorbed in biomass of $C$. cladosporioides. This same eluent (in the same concentration and at $\mathrm{pH}=3.0$, adjusted with $\mathrm{HCl}$ ) was used in the study by Vijayaraghavan et al. (2005), which examined the regeneration of the alga, Ulvaretigulata, after adsorption of $\mathrm{Cu}$ (II), and found that it is efficient in three cycles of sorption-desorption. It is likely that the $\mathrm{HCl}$ acidification favored the potential desorption of calcium chloride.

Until 6 h of contact, the highest average concentration of $\mathrm{Cu}$ (II) desorbed was observed with sulfuric acid. Between 8 and $10 \mathrm{~h}$, ethylenediaminetetraacetate disodium had similar results to both sulfuric acid and hydrochloric acid. Treatment with hydrochloric acid should be avoided when reusing biomass in cycles of sorption/ desorption because this eluent may affect polysaccharide ion exchange and structure.

The behavior of the $\mathrm{Cu}$ (II) concentration desorbed as a function of the contact time for the four eluents is shown in Figure 3 (A, B, C and D). Hydrochloric acid and calcium chloride responded linearly, while ethylenediaminetetraacetate disodium had a quadratic relationship $(p<0.01)$. There was no difference observed with sulfuric acid ( $p>0.05$, Figure $2 \mathrm{~A})$, suggesting that there was no variation in the concentration of $\mathrm{Cu}$ (II) desorbed relative to the times of contact assessed. The values desorbed concentrations of some metals in different biomasses are above those found in the present
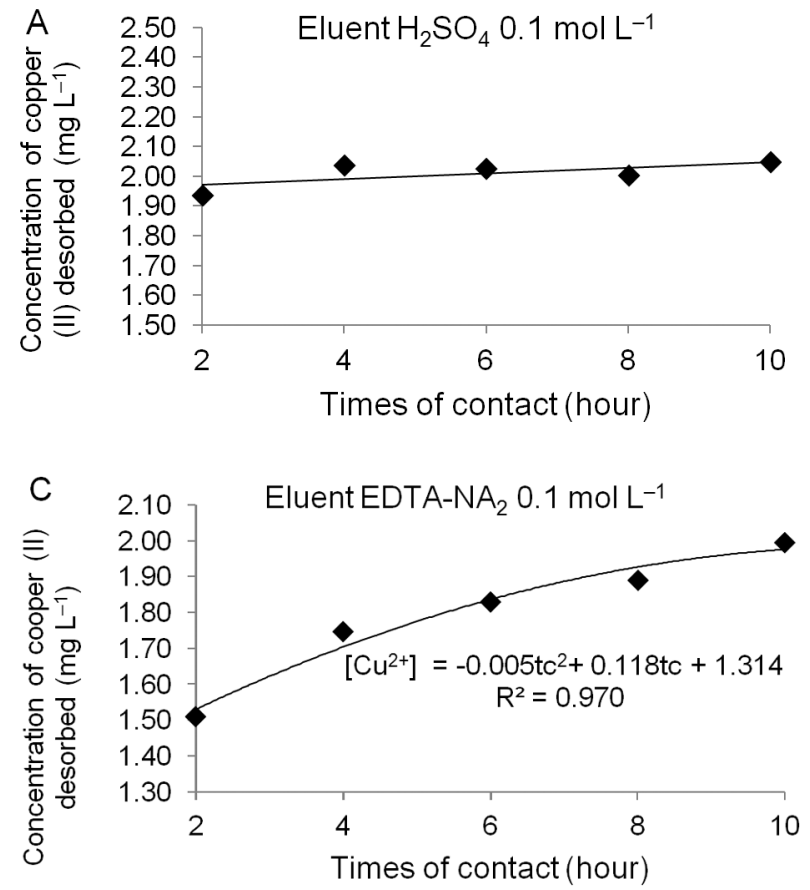

study (Table 2). However, there is a lack of published information in the literature of any test using desorption C. cladosporioides nor the viability of this microorganism after desorption.

Viability of $C$. cladosporioidesafter desorption: the visual comparison of the growth of $C$. cladosporioides after desorption for $10 \mathrm{~h}$ in the eluent solutions showed similar growth with $0.1 \mathrm{~mol} \mathrm{~L}^{-1}$ sulfuric acid and no chemical treatment. All the other eluent solutions inhibited the growth of the C. cladosporioides for up to 12 days of incubation. The preservation of the capacity for biosorption of biomass is as important as the capacity desorbed in the choice of the eluent (Chu et al., 1997); $0.1 \mathrm{~mol} \mathrm{~L}^{-1}$ sulfuric acid is the most effective for both of these.

Table 2 - Desorbed copper from biomasses.

\begin{tabular}{lccc}
\hline Biomass & Eluent & $\begin{array}{c}\text { Desorbed } \\
\text { Copper }\end{array}$ & References \\
\hline $\begin{array}{l}\text { Pycnoporus } \\
\text { sanguineus }\end{array}$ & $0.1 \mathrm{~mol} \mathrm{~L}^{-1}$ & $\%$ & \\
$\begin{array}{l}\text { Penicillium } \\
\text { simplicissimum }\end{array}$ & $\mathrm{HCl}$ & 95 & Zulfadhly et al. (2001) \\
$\begin{array}{l}\text { Phormidiumciano } \\
\text { bacteria }\end{array}$ & $\mathrm{HCl}$ & 98 & Xiao-Ming et al. (2008) \\
$\begin{array}{l}\text { Blue-green algae } \\
\text { Spirulina sp. }\end{array}$ & $\mathrm{EDTA}^{\mathrm{H}}$ & 100 & Blanco et al. (1999) \\
\hline & $\mathrm{HNO}_{3}$ & 98 & Chojnacka et al. (2005) \\
\hline
\end{tabular}
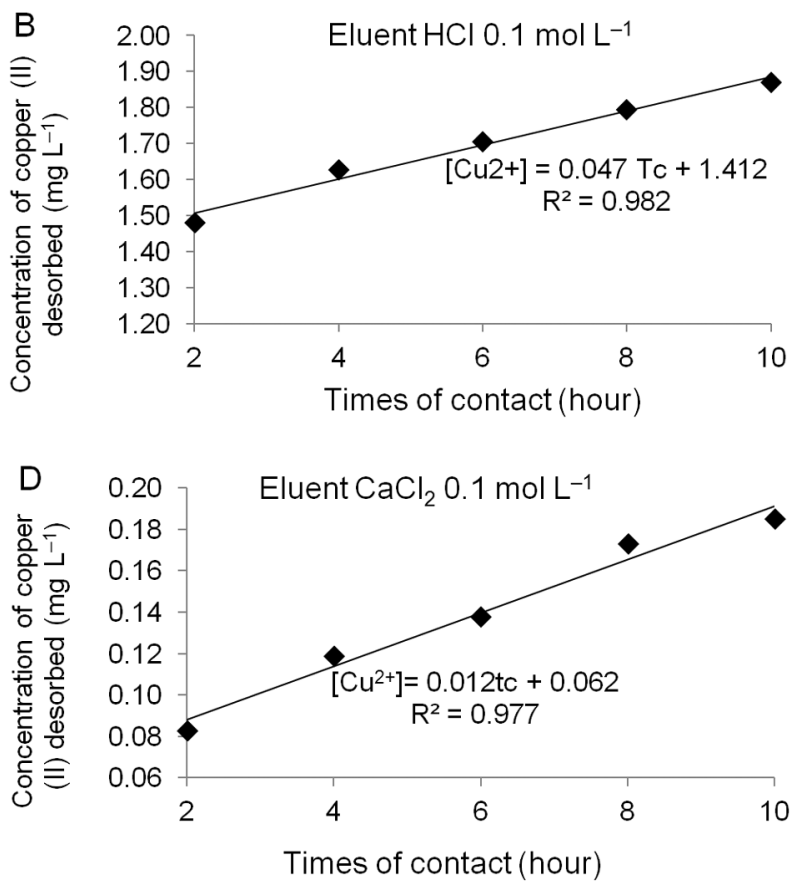

Figure 3 - Variation in the concentration of copper desorbed at different times with the following eluents: (A) sulfuric acid, (B) hydrochloric acid, (C) ethylenediaminetetraacetate disodium and (D) calcium chloride. 
Recovery of $\mathrm{Cu}$ (II) desorbed in the form of copper sulfate hydrous: after the process of sorption-desorption using C. cladosporioides, $900 \mathrm{~mL}$ solution of $0.1 \mathrm{~mol}$ $\mathrm{L}^{-1}$ sulfuric acid, containing $2.02 \mathrm{mg} \mathrm{L}^{-1}$ of $\mathrm{Cu}$ (II), were obtained. In order to recover this metal for the preparation of the solution designed to study the adsorption and desorption process of $\mathrm{CuSO}_{4}$, the $900 \mathrm{~mL}$ volume was reduced to $100 \mathrm{~mL}$ with an electric heating plate, resulting in a concentration of $14.05 \mathrm{mg} \mathrm{L}^{-1}$ of $\mathrm{Cu}$ (II) (corresponding to a mass of $1.405 \mathrm{mg}$ of $\mathrm{Cu}$ II). Thioacetamide (5 mL of solution $3 \% \mathrm{w} / \mathrm{v}$ ) was used as a sulfur source for the precipitation of $\mathrm{Cu}$ (II) in the form of CuS. After precipitation, the precipitate was dried on an electric plate at $60{ }^{\circ} \mathrm{C}$, resulting in a mass of $1.8 \mathrm{mg}$ of $\mathrm{CuS}$, which after oxidation with $2 \mathrm{~mL}$ of concentrated hydrogen peroxide and drying on an electric plate $\left(60{ }^{\circ} \mathrm{C}\right)$, resulted in 4.9 $\mathrm{mg}$ of a solid blue precipitate $\left(\mathrm{CuSO}_{4}\right)$. The $4.9 \mathrm{mg}$ mass of $\mathrm{CuSO}_{4}$ was diluted in up to $1000 \mathrm{~mL}$ of distilled water, resulting in a concentration of $1.15 \mathrm{mg} \mathrm{L}^{-1}$ of $\mathrm{Cu}$ (II). As such, there was a recovery of approximately $63.3 \%$ of the desorbed $\mathrm{Cu}$ (II) in the form of copper sulfate.

\section{Conclusions}

C. cladosporioides can efficiently adsorb Cu (II). 0.1 mol L-1 sulfuric acid was viable and the most efficient in desorbing the absorbed metal, while ensuring viability of the in $C$. cladosporioides after desorption, which is important for the reuse of the biomass in cycles of sorption-desorption.

\section{Acknowledgements}

To EPAMIG/UFLA collection, for providing the $C$. cladosporioides used in the present study.

\section{References}

Andreazza, R.; Pieniz, S.; Wolf, L.; Lee, M.; Camargo, F.; Okeke, B. 2010. Characterization of copper bioreduction and biosorption by a highly copper resistant bacterium isolated from coppercontaminated vineyard soil. Science of the Total Environment 408: 1501-1507.

Blanco, A.; Sanz, B.; Llama, M.J.; Serra, J.L. 1999. Biosorption of heavy metals to immobilised Phormidium laminosum biomass. Journal of Biotechnology 69: 227-240.

Buszman, E.; Pilawa, B.; Zdybel, M.; Wilczynski, S.; Gondzik, A.; Witoszynska, T.; Wilczok, T. 2006. EPR examination of $\mathrm{Zn}^{2+}$ and $\mathrm{Cu}^{2+}$ binding by pigmented soil fungi Cladosporium cladosporioides. Science of the Total Environment 363: 195-205.

Chojnacka, K.; Chojnacki, A.; Górecka, H. 2005. Biosorption of $\mathrm{Cr}^{3+}, \mathrm{Cd}^{2+}$ and $\mathrm{Cu}^{2+}$ ions by blue-green algae Spirulina sp.: kinetics, equilibrium and the mechanism of the process. Chemosphere 59: 75-84.

Chu, K.H., Hashim, M.A., Phang, S.M., Samuel, V.B. 1997. Biosorption of cadmium by algal biomass: adsorption and desorption characteristics. Water Science and Technology 35: 115-122.
Cruz, C.C.V.; Costa, A.C.A.; Henriques, C.A.; Luna, A.S. 2004. Kinetic modeling and equilibrium studies during cadmium biosorption by dead Sargassum sp. biomass. Bioresource Technology 91: 249-257.

Davis, T.A.; Volesky, B.; Mucci, A. 2003. A review of the biochemistry of heavy metal biosorption by brown algae. Water Research 37: 4311-4330.

Dell'amico, E; Mazzocchi, M; Cavalca, L; Allievi, L; Andreoni, V. 2008. Assessment of bacterial community structure in a long-term copper-polluted ex vineyard soil. Microbiological Research 163: 671-683.

Juhasz, A.L.; Smith, E.; Smith, J.; Naidu, R. 2002. Biosorption of organochlorine pesticides using fungal biomass. Journal of Industrial Microbiology and Biotechnology 29: 163-169.

Kaewsarn, P. 2002. Biosorption of copper (II) form aqueous solutions by pre-treated biomass of marine algae Padina sp. Chemosphere 47: 1081-1085.

Luo, J.M.; Xiao, X.; Luo, S.L. 2010. Biosorption of cadmium (II) from aqueous solutions by industrial fungus Rhizopuscohnii. Transactions of Nonferrous Metals Society of China 20: 11041111.

Melgar, M.J.; Alonso, J.; García, M.A. 2007. Removal of toxic metals from aqueous solutions by fungal biomass of Agaricus macrospores. Science of the Total Environment 385: 12-19.

Pethkar, A.V.; Gaikaiwari, R.P.; Paknikar, K.M. 2001a. Biosorptive removal of contaminating heavy metals from plant extracts of medicinal value. Current Science 80: 1216-1219.

Pethkar, A.V.; Kulkarni, S.K.; Paknikar, K.M. 2001b. Comparative studies on metal biosorption by two strains of Cladosporium cladosporioides. Bioreseource Technology 80: 211-215.

Qi, B.; Moe, W.M.; Kinney, K.A. 2002. Biodegradation of volatile organic compounds by five fungal species. Applied Microbiology and Biotechnology 58: 684-689.

Seolatto, A.A.; Câmara, M.M.; Tavares, C.R.; Cossich, E.S.; Silva, E.A. 2009. Removal of nickel (II) from aqueous solutions by Sargassum biomass filipendulain multiplecycles of sorptiondesorption. Acta Scientiarum Technology 31: 57-64 (in Portuguese, with abstract in English).

Silveira, M.L.A.; Alleoni, L.R.F. 2003. Copper adsorption in tropical oxisols. Brazilian Archives of Biology and Technology 46: 529-536.

Statistical Analysis System [SAS]. 1996. SAS/Stat User's Guide: Statistics. SAS Institute, Cary, NC, USA.

Suhasinia, I.P.; Sriram, G.; Abolekar, S.R.; Sureshkumar, G.K. 1999. Biosorptive removal and recovery of cobalt from aqueous systems. Process Biochemistry 34: 239-247.

Vijayaraghavan, K.; Jegan, J.; Palanivelu, K.; Velan, M. 2005. Biosorption of copper, cobalt and nickel by marine green alga Ulva reticulate in a packed column. Chemosphere 60: 419426 .

Xiao-Ming, L.; De-Xiang, L.; Xuen-Qin, X.; Qi, Y.; Guang-Ming, Z.; Wei, Z.; Liang, G. 2008. Kinetic studies for the biosorption of lead and cooper ions by Penicillium simplecissimun immobilized within loofa sponge. Journal of Hazardous Materials 159: 610615.

Zulfadhly, Z.; Mashitah, M.D.; Bhatia, S. 2001. Heavy metals removal in fixed-bed column by the macro fungus Pycnoporus sanguineus. Environmental Pollutions 112: 463-470. 